\title{
Sharia AIS to enhance Islamic Hospital
}

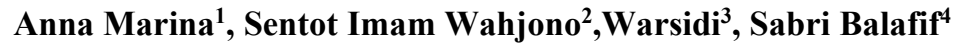 \\ \{anna.marina@fe.um-surabaya.ac.id ${ }^{1}$, sentot.imamw@fe.um-surabaya.ac.id², warsidi@mhes.um- \\ surabaya,ac,id ${ }^{3}$, sabri.b@ft.um-surabaya.ac.id $\left.{ }^{4}\right\}$ \\ ${ }^{1,2}$ Fakultas Ekonomi danBisnis, Universitas Muhammadiyah Surabaya, Indonesia \\ 3,Magister Hukum Ekonomi Islam, Universitas Muhammadiyah Surabaya, Indonesia \\ 4,Fakultas Tehnik, Universitas Muhammadiyah Surabaya, Indonesia
}

\begin{abstract}
Islamic hospitals in Indonesia have grown rapidly in the past 5 years because the majority of the population is Muslim and the awareness to implement Islamic law is getting stronger. The purpose of this study is to find a Sharia Accounting Information System that suits the needs of the Islamic Hospital that is perfecting all financial transactions in the hospital so that it becomes halal and good. This research was conducted with a qualitative approach. The informants used were 9 people as high as Management and above, employees, and 4 experts for triangulation purposes. The findings of this study are that Islamic AIS is needed at this time for better hospital management, by adding 2 digits in the chart of accounts.
\end{abstract}

Keywords: Accounting Information System; informant; Islamic AIS; chart of account.

\section{Introduction}

Hospitals in Indonesia in March 2019 totaled 2,810 [1], this number will continue to grow even more during this Coand pandemic19. Of that number, 500 are Islamic hospitals owned by Islamic institutions or foundations. A total of 20 hospitals have been certified as Sharia Hospitals [2]. In 2020 MUKISI (All Indonesian Islamic Health Efforts Council) targets the number of hospitals that are certified as Sharia Hospitals to be 100. This is because of the amount of public interest in obtaining sharia services at Sharia Hospital. The challenges of Sharia Hospitals in Indonesia are numerous [3] although the majority of Indonesia's population is Muslim [4]. One of the challenges of Syariah Hospital is that hospital service products are not yet perfect in implementing Islamic Sharia in daily health services [5]. Another challenge for Sharia Hospital is that the AIS (accounting information system) used by Sharia Hospital cannot fully provide information on how far the shari'a of a Sharia hospital is [6](Marina, 2019). Another challenge is that the Sharia Hospital must dynamically develop themselves according to the times (Marina, 2018).Therefore, Islamic AIS is needed that allows to be able to know the level of sharia at any time by using AIS software or applications that are already compatible with the rules of the Sharia Hospital.

\section{Literature Review}

Islamic Hospital is a hospital whose activities are based on maqashid al syariah al Islamiyah, maqashid is the plural of the word [7]. So the Islamic hospital is a hospital that is intended to operate based on the Islamic religion. The purpose of the Islamic hospital consists of 5 purposes, namely: Preserving Religion (hifdz ad -din), Preserving Souls (hifdz an-nafs), Preserving 
Descendants (hifdz an-nasl), Preserving Reason (hifdz al-aql), and Preserving the Soul (hifdz almal).The Accounting Information System (AIS), in addition to being used as a management tool for obtaining information, analyzing and deciding, also functions as a tool to account for the authority that has been delegated by management to the management levels below and implementing employees. The responsibility will run smoothly with the help of a system that allows each employee to record and document all events and transactions that occur systematically, orderly, and easily [8].

So, Accounting Information System is a network of all procedures, forms, records, and tools used to process financial data into a form of report that will be used by management in controlling its business activities and subsequently used as a decision-making tool management. SIA is a subsystem which is an integrated business process system that is interrelated with one another. Qualitative characteristics of financial statements that include relevant, reliability can be compared, and can be understood can be generated from a quality SIA, therefore there is a positive relationship between the quality of accounting information with company performance [3].

The accounting information system, in addition to being used as a management tool for obtaining information, analyzing and deciding, also functions as a tool to account for the authority that management has delegated to the levels of management and employees below. The responsibility will run smoothly with the help of a system that allows each employee to record and document all events and transactions that occur systematically, orderly, and easily.The system will process the data entered into a report in accordance with the wishes of management at any time and under any conditions. Therefore we need an integrated system that can cover all hospital activities so that management decisions that are taken based on information from the system are effective and efficient. An integrated information system will support a business process [9].

The integrated information system must start from small systems that cover a certain activity such as accounting information systems [10] The hospital as a social institution that still has to heed the rules of management faces problems in the form of administering patient data, medical data, and financial data. So that administrative services to patients cannot be fast and accurate. Therefore we need the right accounting information system. While SIA Sharia is an AIS that bases itself on fulfilling the provisions of the Islamic religion, namely the Qur'an and al Hadith.

Sharia Accounting Information System Material is prepared by considering the following matters: 1) The theoretical concept of SAK (Financial Accounting Standards) Sharia issued by IAI (Indonesian Accountants Association), 2) Guidelines for hospital management based on sharia principles issued by DSN (Board National Sharia) MUI (Indonesian Ulema Council), 3) Sharia hospital standards and certifications issued by MUKISI (Majelis Upaya Kesehatan Islam Seluruh Indonesia) [11].

Based on the material forming the Islamic AIS above, it can be illustrated in figure 1 regarding Sharia AIS Materials. For internal purposes, Islamic AIS can add 2 additional materials. Adding these materials to fill managerial needs in supporting better decision making. The two materials are: 1) Management needs to improve organizational performance and accountability, 2) The current condition of the organization and the possibility of its development in the future. 


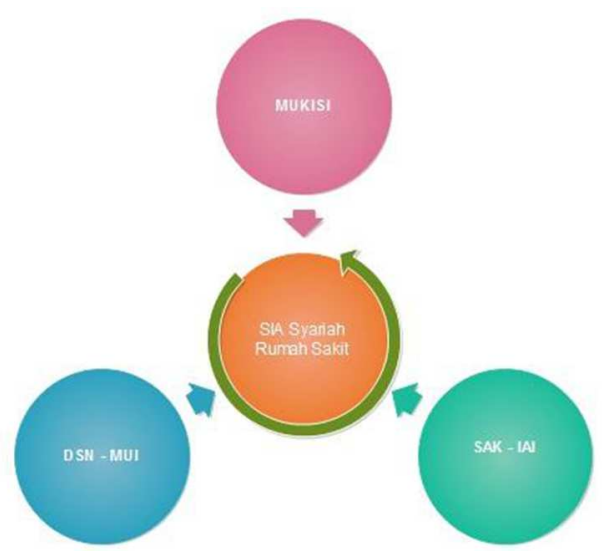

Fig.1. Material of AIS Sharia in Hospitals

\section{Method}

This study uses a qualitative approach, with a purpose to uncover a broader perspective on the Implementation of Islamic Accounting Information System at the hospital. Additionally because of the reality that humans are social and spiritual beings. In their daily activities, human beings can not be treated mechanistic. Research to men with all his behavior in achieving meaningful objectives and the individual interpretation put a man in a unique position included in the decision making. In addition, the study will involve various disciplines (economics, management, organizational behavior, psychology, sociology, and accounting) directs researchers to improve the viewing angle (worldviews) and take the issues and complex problems Creswel [12]

This qualitative study using phenomenological approach that aims to uncover and understand the meaning (noumena) is behind the phenomenon of the actions of individuals who perform various actions on the basis of their own perceptions as well as various aspects of the underlying actions qualitative. The research was conducted with data collection by the Focus Group Discussion (FGD), depth interview and outside observation. With in-depth interviews, a series of questions prepared with the aim to answer the research question. The question posed was not structured but flows to the rhythm of the time of the FGD and in-depth interview with a view to eliminating the rigid and drab atmosphere. Meanwhile external observation was conducted to obtain an objective perspective on some of the findings were found either through interviews or found through secondary data. Observations from the outside are also useful to obtain a starting material when designing or designing research questions.

FGD was held on March 11, 2020, involving 20 employees yang berhubungan dengan keuangan dan akuntansi. FGD was attended by Director of RSUAP (Rumah Sakit Umum Aisyiyah Ponorogo) and all leaders including 2 Deputy Director and Head of Section 5. FGD position is set in a circle, in which 20 participants seated at a table opposite, at the end of the left circle sit moderator (expert FGD) and principal investigator. On the far right of the circle sits 2 documenter. Medium 1 documenters freestanding move along the room to document and serve the course of FGD.

Depth interviews conducted during the period of 3 months from March 10 to May 10, 2020, involving a Director, 2 Deputy Director and Head of Section 5. In-depth interviews conducted flexibly by the presence and timeliness. Interviews sometimes held in the office, while walking 
reviewing the condition of the hospital, or when interviewees running the next day. Interviews were also conducted outside of working hours and outside the hospital.

Observations from the outside is held during the period of 3 months from March 10 to May 10, 2020. These observations put themselves researcher as an outsider who has no connection with RSUAP. Observations were made to the patient, the patient's family, without the knowledge of employees and management are observed. Observations conducted in order to confirm the above findings for FGD and in-depth answer answers during the interview. During this observation period had also conducted interviews with 10 patients and their families.

Triangulation was held to test the validity of their answers during the FGD and in-depth interview answers. Triangulation is also carried out to test the reliability 9 topics asked during focus group discussions and in-depth interviews. Triangulation is done by asking the opinion of four experts on Muhammadiyah studies and the experts on social, environmental and especially ASEAN and Indonesian studies. Experts are Prof. Dr. Moeghni Shafiq (one Chairman of Muhammadiyah Central Executive in charge of social welfare and hospitals, was formerly the Chairman of the Regional Chairman of Muhammadiyah East Java), then Prof. Dr. Jainuri (one Chairman of Muhammadiyah Regional Leadership of East Java and also former Rector of the Universitas Muhammadiyah Sidoarjo), Prof. Dr. Zainuddin Maliki (Chairman of the Advisory Board of the National Agency for Disaster Management and former rector of Muhammadiyah Surabaya), and dr. Sugeng Ristanto, MARS (assessors national hospital, the former director of a private hospital in Surabaya). The interview with experts (expert informant) conducted during the period of study is 3 months starting from March 10 to May 10, 2020.

\section{Result And Discussion}

\section{Interview Results}

Interview questions based on the objectives of sharia hospitals which consist of 5 purposes, namely: Preserving Religion (hifdz ad-in), Nurturing the Soul (hifdz an-nafs), Nurturing Descendants (hifdz an-nasl), Preserving Reason (hifdz al-aql), and Maintaining Assets (hifdz almal). Meanwhile AIS Sharia material includes Accounting Policies, Account Lists and Codes, Input Media, Bookkeeping Media, Forms, Tools and Equipment, and Software.

Table 1. Interview Result from 12 informan

\begin{tabular}{|c|c|c|c|c|c|}
\hline & $\begin{array}{c}\text { Maintaining } \\
\text { Religion }\end{array}$ & $\begin{array}{l}\text { Nourish the } \\
\text { Soul }\end{array}$ & $\begin{array}{l}\text { Nurturing } \\
\text { Heredity }\end{array}$ & $\begin{array}{l}\text { Maintaining } \\
\text { Intellect }\end{array}$ & $\begin{array}{l}\text { Maintaining } \\
\text { Property }\end{array}$ \\
\hline Director & $\begin{array}{l}\text { Accounting } \\
\text { policy avoids } \\
\text { usury (riba) }\end{array}$ & $\begin{array}{l}\text { Accounting } \\
\text { policy calms } \\
\text { the soul }\end{array}$ & $\begin{array}{l}\text { Accounting } \\
\text { policies sustain } \\
\text { life }\end{array}$ & $\begin{array}{l}\text { Software used is } \\
\text { in accordance } \\
\text { with logic }\end{array}$ & $\begin{array}{l}\text { Accounting policy } \\
\text { does not make } \\
\text { patients poor }\end{array}$ \\
\hline $\begin{array}{l}\text { Deputy } \\
\text { Director } 1\end{array}$ & $\begin{array}{l}\text { The account code } \\
\text { separates usury } \\
\text { and non-usury }\end{array}$ & $\begin{array}{l}\text { The forms used } \\
\text { to reassure the } \\
\text { soul }\end{array}$ & $\begin{array}{l}\text { Drugs and } \\
\text { medical supplies } \\
\text { used to maintain } \\
\text { good offspring }\end{array}$ & $\begin{array}{l}\text { The forms used } \\
\text { is in accordance } \\
\text { with the logic }\end{array}$ & $\begin{array}{l}\text { Drugs and } \\
\text { medical devices } \\
\text { used do not make } \\
\text { patients poor }\end{array}$ \\
\hline $\begin{array}{l}\text { Deputy } \\
\text { Director } 2\end{array}$ & $\begin{array}{l}\text { The forms used } \\
\text { are religious }\end{array}$ & $\begin{array}{l}\text { Accounting } \\
\text { software calms } \\
\text { the soul }\end{array}$ & $\begin{array}{l}\text { Account code } \\
\text { does not make it } \\
\text { infertile }\end{array}$ & $\begin{array}{l}\text { Chart of } \\
\text { Account is in } \\
\text { accordance with } \\
\text { common sense }\end{array}$ & $\begin{array}{l}\text { Equipment and } \\
\text { equipment does } \\
\text { not burden the } \\
\text { patient's finances }\end{array}$ \\
\hline $\begin{array}{l}\text { Head } \\
\text { Section } \\
\text { Finance }\end{array}$ & $\begin{array}{l}\text { Religious } \\
\text { software }\end{array}$ & $\begin{array}{l}\text { Drugs and } \\
\text { medical } \\
\text { supplies used to } \\
\text { preserve the }\end{array}$ & $\begin{array}{l}\text { Input media and } \\
\text { bookkeeping } \\
\text { media motivate } \\
\text { offspring }\end{array}$ & $\begin{array}{l}\text { Accounting } \\
\text { policies follow } \\
\text { coherent } \\
\text { common sense }\end{array}$ & $\begin{array}{l}\text { The software is } \\
\text { cheap }\end{array}$ \\
\hline
\end{tabular}




\begin{tabular}{|c|c|c|c|c|c|}
\hline $\begin{array}{l}\text { Head of } \\
\text { Section } \\
\text { Accounting }\end{array}$ & $\begin{array}{l}\text { Computers and } \\
\text { equipment are } \\
\text { lawful (halal) and } \\
\text { good }\end{array}$ & $\begin{array}{l}\text { soul } \\
\text { Chart of } \\
\text { Account is } \\
\text { escorted by } \\
\text { DPS (Sharia } \\
\text { Supervisory } \\
\text { Board) }\end{array}$ & $\begin{array}{l}\text { strengthening } \\
\text { Accounting } \\
\text { policies sustain } \\
\text { life }\end{array}$ & $\begin{array}{l}\text { Input media and } \\
\text { bookkeeping } \\
\text { media are not } \\
\text { complicated }\end{array}$ & $\begin{array}{lr}\text { Low-cost input } \\
\text { media } \\
\text { bookkeeping } \\
\text { media }\end{array}$ \\
\hline Moeghni S & $\begin{array}{l}\text { The hospital sets } \\
\text { the standard } \\
\text { operating } \\
\text { procedures for } \\
\text { admitting, } \\
\text { guiding and } \\
\text { returning patients }\end{array}$ & $\begin{array}{l}\text { Hospital } \\
\text { provides sharia } \\
\text { services }\end{array}$ & $\begin{array}{l}\text { Hospital provides } \\
\text { sharia maternal } \\
\text { and infant health } \\
\text { services }\end{array}$ & $\begin{array}{l}\text { The hospital } \\
\text { carries out } \\
\text { religious } \\
\text { mandatory } \\
\text { training for all } \\
\text { employees }\end{array}$ & $\begin{array}{l}\text { The hospital } \\
\text { cooperates with } \\
\text { Islamic financial } \\
\text { institutions in cash } \\
\text { management, } \\
\text { financing and } \\
\text { investment }\end{array}$ \\
\hline Jaenuri & $\begin{array}{l}\text { The hospital } \\
\text { complements } \\
\text { transportation } \\
\text { standards with } \\
\text { Islamic audio or } \\
\text { video media }\end{array}$ & $\begin{array}{l}\text { The hospital } \\
\text { provides sharia } \\
\text { pain } \\
\text { management } \\
\text { services }\end{array}$ & $\begin{array}{l}\text { The hospital } \\
\text { provides Islamic } \\
\text { reproduction } \\
\text { services }\end{array}$ & $\begin{array}{l}\text { The hospital } \\
\text { provides a } \\
\text { library that } \\
\text { contains Islamic } \\
\text { literature }\end{array}$ & $\begin{array}{l}\text { Hospitals have } \\
\text { policies and } \\
\text { mechanisms for } \\
\text { patients who are } \\
\text { unable to pay }\end{array}$ \\
\hline $\begin{array}{l}\text { Zaenuddin } \\
\text { M }\end{array}$ & $\begin{array}{l}\text { The hospital } \\
\text { establishes a } \\
\text { spiritual } \\
\text { assessment for } \\
\text { the patient to } \\
\text { obtain the } \\
\text { patient's religious } \\
\text { data }\end{array}$ & $\begin{array}{l}\text { Regulation of } \\
\text { sharia waste } \\
\text { management of } \\
\text { human body } \\
\text { tissue }\end{array}$ & $\begin{array}{l}\text { Hospital provides } \\
\text { sharia maternal } \\
\text { and infant health } \\
\text { services }\end{array}$ & $\begin{array}{l}\text { Sharia } \\
\text { settlement of } \\
\text { complaints, } \\
\text { conflicts } \\
\text { differences or } \\
\text { opinion }\end{array}$ & $\begin{array}{l}\text { he hospital set the } \\
\text { SOP to find out } \\
\text { the miscalculated } \\
\text { billing }\end{array}$ \\
\hline Sugeng R & $\begin{array}{l}\text { The hospital } \\
\text { establishes } \\
\text { policies and } \\
\text { procedures for } \\
\text { treating high-risk } \\
\text { patients and } \\
\text { terminal stages }\end{array}$ & $\begin{array}{l}\text { Procurement of } \\
\text { water sources } \\
\text { in accordance } \\
\text { with Islamic } \\
\text { principles }\end{array}$ & $\begin{array}{l}\text { The hospital } \\
\text { provides Islamic } \\
\text { reproduction } \\
\text { services }\end{array}$ & $\begin{array}{l}\text { Education and } \\
\text { training help the } \\
\text { fulfillment of } \\
\text { Islamic health } \\
\text { in a sustainable } \\
\text { manner from } \\
\text { patients }\end{array}$ & $\begin{array}{l}\text { The hospital } \\
\text { cooperates with } \\
\text { Islamic financial } \\
\text { institutions in cash } \\
\text { management, } \\
\text { financing and } \\
\text { investment }\end{array}$ \\
\hline Employee A & $\begin{array}{l}\text { The hospital } \\
\text { guarantees halal, } \\
\text { hygienic, food } \\
\text { safety and } \\
\text { nutritional } \\
\text { therapy given to } \\
\text { patients }\end{array}$ & $\begin{array}{l}\text { The hospital } \\
\text { provides sharia } \\
\text { pain } \\
\text { management } \\
\text { services }\end{array}$ & $\begin{array}{l}\text { Hospital provides } \\
\text { sharia maternal } \\
\text { and infant health } \\
\text { services }\end{array}$ & $\begin{array}{l}\text { Islamic } \\
\text { education to } \\
\text { visitors of the } \\
\text { hospital }\end{array}$ & $\begin{array}{lr}\text { Hospitals have } \\
\text { policies and } \\
\text { mechanisms for } \\
\text { patients who are } \\
\text { unable to pay }\end{array}$ \\
\hline Employee B & $\begin{array}{l}\text { The hospital } \\
\text { guarantees an } \\
\text { effort to maintain } \\
\text { the patient's } \\
\text { genitals, services } \\
\text { according to } \\
\text { gender and } \\
\text { maintain the } \\
\text { element of } \\
\text { ikhtilath }\end{array}$ & $\begin{array}{l}\text { Regulation of } \\
\text { sharia waste } \\
\text { management of } \\
\text { human body } \\
\text { tissue }\end{array}$ & $\begin{array}{l}\text { The hospital } \\
\text { provides Islamic } \\
\text { reproduction } \\
\text { services }\end{array}$ & $\begin{array}{l}\text { The hospital } \\
\text { carries out } \\
\text { religious } \\
\text { mandatory } \\
\text { training for all } \\
\text { employees }\end{array}$ & $\begin{array}{l}\text { The hospital set } \\
\text { the SOP to find } \\
\text { out } \\
\text { miscalculated } \\
\text { billing }\end{array}$ \\
\hline Employee C & $\begin{array}{l}\text { The hospital } \\
\text { guarantees } \\
\text { anesthetic and } \\
\text { surgical service } \\
\text { efforts according } \\
\text { to sharia }\end{array}$ & $\begin{array}{l}\text { Procurement of } \\
\text { water sources } \\
\text { in accordance } \\
\text { with Islamic } \\
\text { principles }\end{array}$ & $\begin{array}{l}\text { The hospital } \\
\text { provides Islamic } \\
\text { reproduction } \\
\text { services }\end{array}$ & $\begin{array}{l}\text { The hospital } \\
\text { provides a } \\
\text { library that } \\
\text { contains Islamic } \\
\text { literature }\end{array}$ & $\begin{array}{l}\text { Hospitals have } \\
\text { policies and } \\
\text { mechanisms for } \\
\text { patients who are } \\
\text { unable to pay }\end{array}$ \\
\hline
\end{tabular}


To summarize the results of the informant's interview that the ideal Sharia SIA needed for Sharia Hospitals in Indonesia is those that meet the following criteria:

1. Islamic Hospital Concept

2. Islamic Maqosit Hospital

3. Accounting Information System

4. The Software develop by Iteratif Model with UML (Unified Modelling Language) for Database Server using MySQL and PHP as Compiler.

5. Islamic Accounting Information System for Hospital

So that the Islamic Accounting Information System For Hospital can be illustrated in Figure 2.

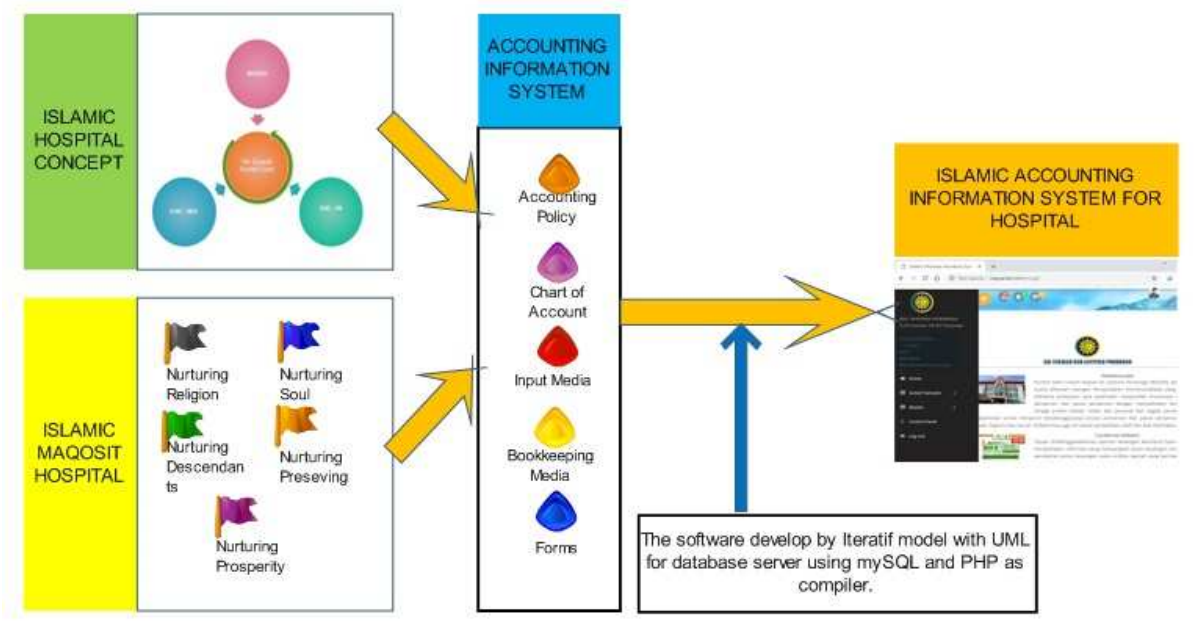

Fig.2. Islamic Accounting Information System for Hospital

The Islamic Accounting Information System for Hospital is arranged based on: 1. The Sharia concept of the Hospital is prepared by considering: The theoretical concept of SAK (Financial Accounting Standards) Sharia issued by IAI (Indonesian Institute of Accountants). [8], b. Guidelines for the organization of hospitals based on sharia principles issued by DSN (National Sharia Council) MUI (Indonesian Ulema Council). [9], c. Sharia hospital standards and certifications issued by MUKISI (All Indonesian Islamic Health Efforts Council) [10], d. Islamic Accounting Information System For Hospital [11].

The Islamic Accounting Information System for Hospital was built based on: 2. Purpose of Sharia Runah Hospital [6] as a basis for the operation of hospitals based on Islam with 5 purposes: a. Maintaining Religion (hifdz ad-INdi), b. Nurturing the Soul (hifdz an-nafs), c. Maintaining descent (hifdz an-nasl), d. Maintaining Intellect (hifdz al-aql), and e. Preserving Assets (hifdz almal).

Islamic Accounting Information System for Hospital compiled based on: 3. Accounting Information System [6] with basic components: a. Accounting Policy, b. Account List and Code, c. Media Input, d. Bookkeeping Media, and e. Forms.

Islamic Accounting Information System for Hospital with Software developed according to the Iterative model with UML for database servers using mySQL and PHP as compilers. [12]. 
This study found evidence that Islamic AIS is indispensable for Sharia Hospital, this is in line with research findings Marina et al [8] also [9]. That AIS is implemented in a hospital can improve internal control [10].

The research findings also state the need for hospitals for AIS that are mobile and using a cloud approach. This finding is in line with Brandas et al [11]. The challenge of AIS for better business management is the need for the Real-Time Reporting, the need for reports generated by hospitals is very necessary for better hospital management, dynamic and controlable. This finding is in line with Trigo [2]. An important finding of this research is the need to make 2 digits inserted in the chart of account to identify a transaction that is classified as a halal, doubtful, or haram transaction.

\section{Conclusion}

This research proves that in order to perfect Sharia Financial Statements at Sharia Hospitals a special Chart of Account is needed that can be used to identify the willingness of a transaction.

\section{References}

[1] L. T. E. Listyani, "Jumlah Rumah Sakit di Indonesia,” Manajemen Rumah Sakit, 2019. https://manajemenrumahsakit.net/2018/04/jumlah-rumah-sakit-di-indonesia/.

[2] Masyhudi, "Mukisi Tambah Jumlah RS Syariah di Tahun 2019," Mukisi, Jakarta, p. 20, Aug. 2020

[3] R. Noordin, Y. Zainuddin, Fuad, R. Mail, and N. K. Sariman, "Performance Outcomes of Strategic Management Accounting Information Usage in Malaysia: Insights from Electrical and Electronics Companies," Procedia Econ. Financ., vol. 31, no. 15, pp. 13-25, 2015, doi: 10.1016/s22125671(15)01127-2.

[4] S. Nikmah, "Konsep Rumah Sakit Syariah Dan Implementasinya Di Rumah Sakit Muhammadiyah Lamongan," 2019.

[5] D. Wiji, P. Sari, M. Abdurrouf, F. I. Keperawatan, U. Islam, and S. Agung, "Pelayanan keperawatan berbasis syariah dan loyalitas pasien di rumah sakit islam," J. Keperawatan dan Pemikir. Ilm., vol. 4, no. 7, pp. 109-117, 2018.

[6] A. Marina, S. I. Wahjono, And F. A. M. S. O. O. Fen, "Islamic Accounting Information System Development :," 2018, Pp. 1-4, [Online]. Available: Https:/Www.Worldresearchlibrary.Org/Up Proc/Pdf/1938-154097741301-04.Pdf.

[7] F. Jesús Plaza del Pino, "Nurses and Muslim Patients: Two Perspectives on Islamic Culture in the Hospital," Procedia - Soc. Behav. Sci., vol. 237, no. June 2016, pp. 1131-1137, 2017, doi: 10.1016/j.sbspro.2017.02.167.

[8] A. Trigo, F. Belfo, and R. P. Estébanez, "Accounting Information Systems: Evolving towards a Business Process Oriented Accounting," Procedia Comput. Sci., vol. 100, pp. 987-994, 2016, doi: 10.1016/j.procs.2016.09.264.

[9] K. Bouafia and B. Molnár, "Analysis approach for enterprise information systems architecture based on hypergraph to aligned business process requirements," Procedia Comput. Sci., vol. 164, pp. 1924, 2019, doi: 10.1016/j.procs.2019.12.149.

[10] C. Xu, Y. Fang, and Y. Ma, "Integrated Application of Blockchain in the Electric Information Management System,” Procedia Comput. Sci., vol. 162, no. Itqm 2019, pp. 88-93, 2019, doi: 10.1016/j.procs.2019.11.262.

[11] A. Marina, S. I. Wahjono, M. Sya'ban, and A. Suarni, Sistem Informasi Akuntansi, dengan pengenalan sistem informasi akuntansi syariah, 1st ed. Depok, Jakarta: RajaGrafindo Persada, 2019.

[12] J. D. Creswell, John W., Creswell, Research Design. Qualitative, Quantitative, and Mixed Methods Approaches., Fifth. London, 2018. 